\section{УДК 339.9:330.101}

\section{JEL classification: F23, F31}

\section{Анна МАКСИМЕНКО}

кандидат економічнихнаук, професор, кафедра міжнародного обліку і аудиту, ДВНЗ «Київський національний економічний університет імені Вадима Гетьмана», Україна

E-mail: an-maksimenko@ukr.net http://www.researcherid.com/rid/M-18562018

ORCID: https://orcid.org/0000-0001-7122-0332

(C) Анна Максименко, 2020

Отримано: 14.11.2020 р.

Прорецензовано: 28.11.2020 p.

Рекомендовано до друку: 16.12.2020 p.

Опубліковано: 16.12.2020р.

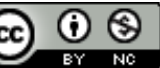

Ця стаття розповсюджується на умовах ліцензії Creative Commons Attribution NonCommercial 4. 0, яка дозволяє необмежене повторне використання, розповсюдження та відтворення на будь-якому носії, за умови правильногоцитування оригінальної роботи.
Анна Максименко (Україна)

\section{ПРОБЛЕМИ I ПЕРСПЕКТИВИ ДІЯЛЬНОСТІ ТНК}

\section{АНОТАЦІя}

Вступ. Транснаціональні корпорації одне з найважливіших і найбільш домі нуючих явищ суча сної світової економіки, які вносять якісно нові зміни в міжна родний економічний простір. Процес концентрації в окремих секторах різко набирає швидкість; збільшуються об'єми досліджень та розробок, виробничого, маркетингового ланцюга та мереж обслуговува ння змі нюється. Нові форми спеціалізації, інституці она лізація тра нсна ці она льних і нститутів, створення глоба льних потоківі процесів режимі реального часу, включа ючи нове розуміння структури та змін порівняльних переваг країн та територій; все це змінює загальний вигляд глоба льного економічного розвитку. Зростання кількості транснаціональних компаній та їхньої діяльності також відображається у змінах галузевої структури та пов'язаних із цим змінах у географічній структурі діяльності ТНК.

Мета статті ідентифі кувати проблеми діяльності ТНК та оцінити перспективи економічних трансформацій.

Метод. При вирішенні завдань використовувались загальнонаукові та спеціальні методи: узагальнення, аналізу та синтезу, системного підходу, гра фічного аналізу.

Результати. В роботі дана комплексна характеристика домінуючих тренді в міжнародної діяльності ТНК. Оцінка географічної структури найпотужніших світових ТНК доводить лідерство США середбільшості країн, проте з кожним роком їх роль зменшується та зростає вплив Китаю. Оцінюючи глобальну зміну контурів міжнародної діяльності ТНК доведено, що ТНК за своєю природою, рушійними силами, векторною спрямованістю і механізмом розвитку на усіх етапах світогосподарського поступу яскраво викриста лізовує системні фінансові дисбаланси. Доведено, що припинення комерційної діяльності в умовах пандемії Коронавірусу (Covid-19) матиме негативний вплив на світовуекономіку. Як свідчать дані, фізичне закриття підприємств, виробничих підприємств та будівельних майданчиків спричинило негайні затримки уреа лізації інвестиційних проектів. Поді бним чином постра жда ли злиття та поглинання, які в першій половині 2020 року в цілому скоротились на 50-70\%. Однак не на всі компаніїнегативно впливає пандемія. Найбільші гра вці електронної комерції, пережили зростання за вдяки зростанню кі лькості покупок в Інтернеті.

Максименко А. Проблеми і перспективи діяльності ТНК. Економічний аналіз. 2020. Том 30. № 3. С. 182-189.

DOI: https://doi.org/10.35774/econa2020.03.182

Ключові слова: транснаціональні корпорації; прямі іноземні інвестиції; глобалізація; світова економіка. 


\section{UDC 339.9:330.101}

\section{JEL classification: F23, F31}

\section{Anna MAKSYMENKO}

\section{PhD in Economics,}

Professor,

Department of International Accounting and Auditing,

Kyiv National Economic University named after Vadym Hetman, Ukraine

E-mail: an-maksimenko@ukr.net

http://www.researcherid.com/rid/M-1856-

2018

ORCID: https://orcid.org/0000-0001-7122-0332

(C) Anna Maksymenko, 2020

Received: 14.11 .2020

Revised: 28.11.2020

Accepted:16.12.2020

Online publication date: 16.12 .2020

\section{(c) (1) \&}

This is an Open Access article, distributed under the terms of the Creative Commons AttributionNonCommercial 4. 0 license, which permits unrestricted re-use, distribution, and reproduction in any medium, provided the original work is properly cited.
Anna Maksymenko (Ukraine)

\section{PROBLEMS AND PROSPECTS OF TNC ACTIVITY}

\begin{abstract}
Introduction. Transnational corporations a re one of the most important and most dominant phenomena of the modern world economy, which make qualitatively new changes in the international economic space. The process of concentration in some sectors is rapidly gaining momentum; R\&D increases, production, marketing chain and service networks change. New forms of specialization, institutionalization of tra nsnational institutions, creation of global flows and processes in real time, including a new understanding of the structure and changes in the comparative advantages of countries and territories; all this changes the general vi ew ofglobal economic development. The growth in the number of multinational companies and their activities is also reflected in changes in the sectoral structure and related changes in the geographical structure of TNCS.

The purpose of the article is to identify the problems of TNCS and assess the prospects for economic transformation.

Method. In solving problems, general scientific and special methods were us ed: generalization, a nalysis a nd synthesis, sys tem approach, graphical analysis. Results. The paper presents a comprehensive description of the dominant trends in the international activities of TNCS. The assessment of the geographical structure of the world's most powerful TNCs proves the leadership of the United Sta tes among most countries, but each year their role decreases and China's influence grows. Assessing the gl obal change in the contours of the international activities of TNCS, it is proved that TNCS by their nature, driving forces, vector orientation and development mechanism at all stages of world economic progress cl early crys tallize systemic fi nanciali mbalances. It has been proven that the cessation of commercial activity in the context of the Coronavirus pande mic (Covid-19) will have a negative impact on the world economy. According to the da ta, the physical closure of enterprises, production enterprises and construction sites ca used immediate delays in the implementation of investment projects. Mergers and acquisitions we re similarly affected, which in the first half of 2020 generally decreased by $50-70 \%$. However, not all companies are negatively affected by the pandemic. The biggest e-commerce players have experienced growth due to the growth of online shopping.
\end{abstract}

Maksymenko, A. (2020). Problems and prospects of TNC activity. Economic analysis, 30 (3), 182-189.

DOI: https://doi.org/10.35774/econa2020.03.182

Keywords: tra ns national corporations; foreign direct investment; globalization; the world economy. 


\section{Вступ}

Транснаціональні корпорації (ТНК) відіграють ключову роль у процесі глобалізації. Їх стратегії багато в чому визначають обсяг i характер торгівельних шляхів, прямих іноземних інвестицій та фінансових потоків. Детермінанти цих стратегій самі по собі $є$ досить складними. Вони враховують не лише фактори витрат та конкретні активи країн, а й складний зв'язок зовнішніх мереж та національних процедур, а також власні ноу-хау, які, всупереч деяким переконанням, все ще значною мірою впливають на країну походженням. Особливості ТНК виявляється у складі їх правління, у формі їх внутрішньої організації, а також у характері та географії транзакцій, в яких вони $\epsilon$ більш конкурентоспроможними.

Розвиток транснаціонального бізнесу дозволяє припустити, що еволюція організаційних структур, які оперують у ньому, веде до поглиблення суспільного характеру сучасного виробництва та його інтернаціоналізації, а невідповідність ії мінливих умов не тільки знижує ефективність діяльності конкретного суб'єкта, але й може стримувати економічне зростання в національній i світовій економіці, оскільки цей процес органічно пов'язаний зі зрушеннями в самій структурі глобальної торговельної системи, виникненням нових форм і моделей. Зростання кількості транснаціональних компаній та їхньої діяльності також відображається у змінах у галузевій структурі та пов'язаних із цим змінах у географічній структурі діяльності ТНК.

Теоретико-методологічною основою роботи $€$ фундаментальні праці представників економічної теорії, дослідження зарубіжних та вітчизняних економістів, присвячених вивченню проблем позиціонування транснаціональних корпорацій в процесах глобалізації світової економіки.

Дослідження процесів глобалізації та ролі ТНК в системі міжнародних економічних відносин брало участь велика кількість вітчизняних та зарубіжних економістів, серед яких: В. Белошапка, О. Білорус, Д. Лук'яненко, 3. Луцишин, Н. Мешко, О. Мозговий, Ю. Макогон, В. Рокоча, Т. Орєхова, О. Плотнікова, А. Поручник, Є. Панченко, М. Портер, А.Ругман, Л. Руденко-Сударева, Д. Стопфорд, Я. М. Столярчук, А. Страут, М. Тейлор, А. Філіпенко.

Незважаючи на велику кількість опрацьованих теоретичних та прикладних питань, питання позиціонування транснаціональних корпорацій в процесах глобалізації світової економіки, виявлення позитивних сторін та існуючих загроз транснаціональних корпорацій, а також шляхи їх запобігання та мінімізації залишаються недостатньо дослідженими.

\section{Мета статті}

Мета статті ідентифікувати проблеми діяльності THк та оцінити перспективи економічних трансформацій.

\section{Виклад основного матеріалу дослідження}

Найзручніший спосіб здійснювати аналіз діяльності ТНК на сьогоднішній день $\epsilon$ використання різноманітних індексів, що створені міжнародними організаціями, таких як індекс транснаціоналізації (TNI), індекс інтерналізації (II), індекс географічного поширення діяльності (GSI) та інші. У даній роботі для аналізу діяльності ТНК використовується індекс Global 2000 розроблений виданням Forbes. Список Global 2000 складається, 3 використанням даних 3 дослідницьких систем FactSet, щоб визначити найбільші компанії за чотирма показниками: продажі, прибуток, активи та ринкова вартість.

Аналізуючи географічну структуру районуванням світової економіки, за даними рейтингу Forbes в 2019 р. серед ТНК за багатьма параметрами переважали фірми з США, КНР, Японії, Великобританії, Франції та Німеччини (рис. 1). 2 тисячі компаній, що потрапили у щорічний рейтинг найбільших публічних компаній у світі Global 2000, мають щорічний дохід понад 40 трлн дол. США та глобальні активи понад 186 трлн дол. США [1].

У топ-10 за кількістю фірм-мільярдерів увійшли США (575 фірм) та KНP (309) - це єдині країни зі списку, в яких кількість компаній-гігантів істотно збільшується. Круті обмеження ринку та відповідні тарифи - це останні події, що посилюють торговельну напруженість між США та Китаєм. Якщо коли-небудь стався переломний момент в економічному перетягуванні каната між найбільшими економіками світу, це зараз. 61 країна отримала місце в цьому щорічному рейтингу найбільших компаній світу, але концентрація влади, безсумнівно, на користь США та Китаю [1]. У першу трійку списку держав 3 найбільшою кількістю крупних компаній, в яких загалом входить 61 країна, попала також Японія (223).

Динаміка кількості провідних ТНК у США та КНР упродовж 2003-2019 рр. подана у рис. 2. 


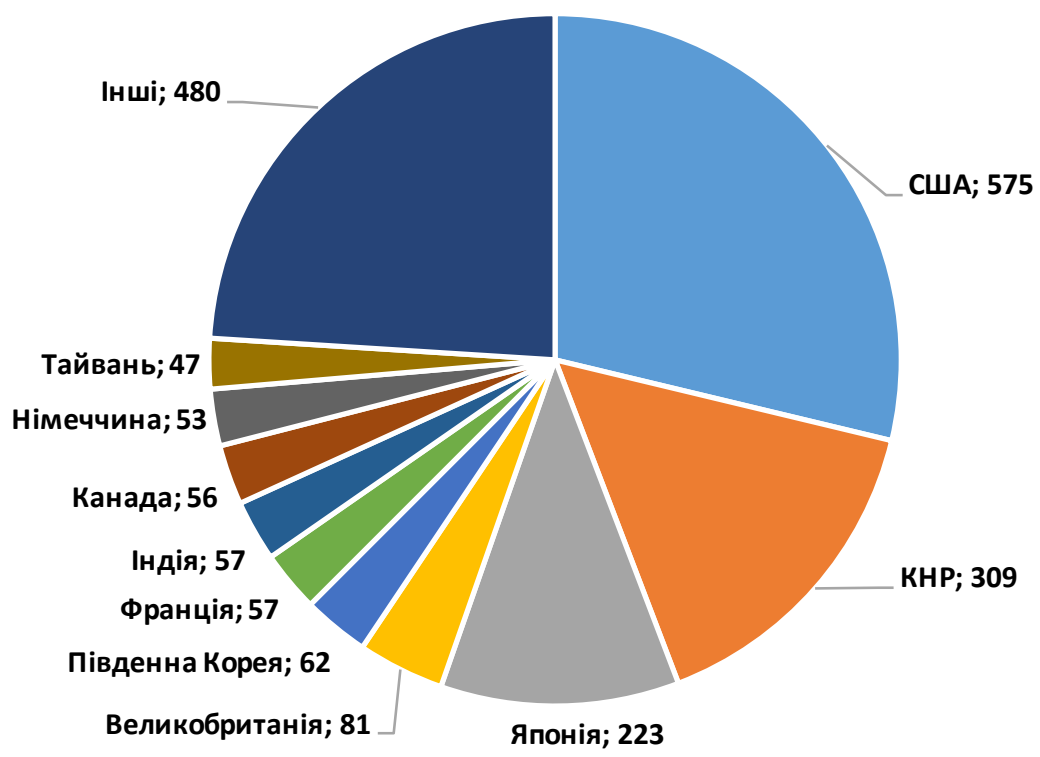

Рис. 1. Географічна структура найпотужніших споживчих ТНК в світі за версією Forbes-2019 [1]

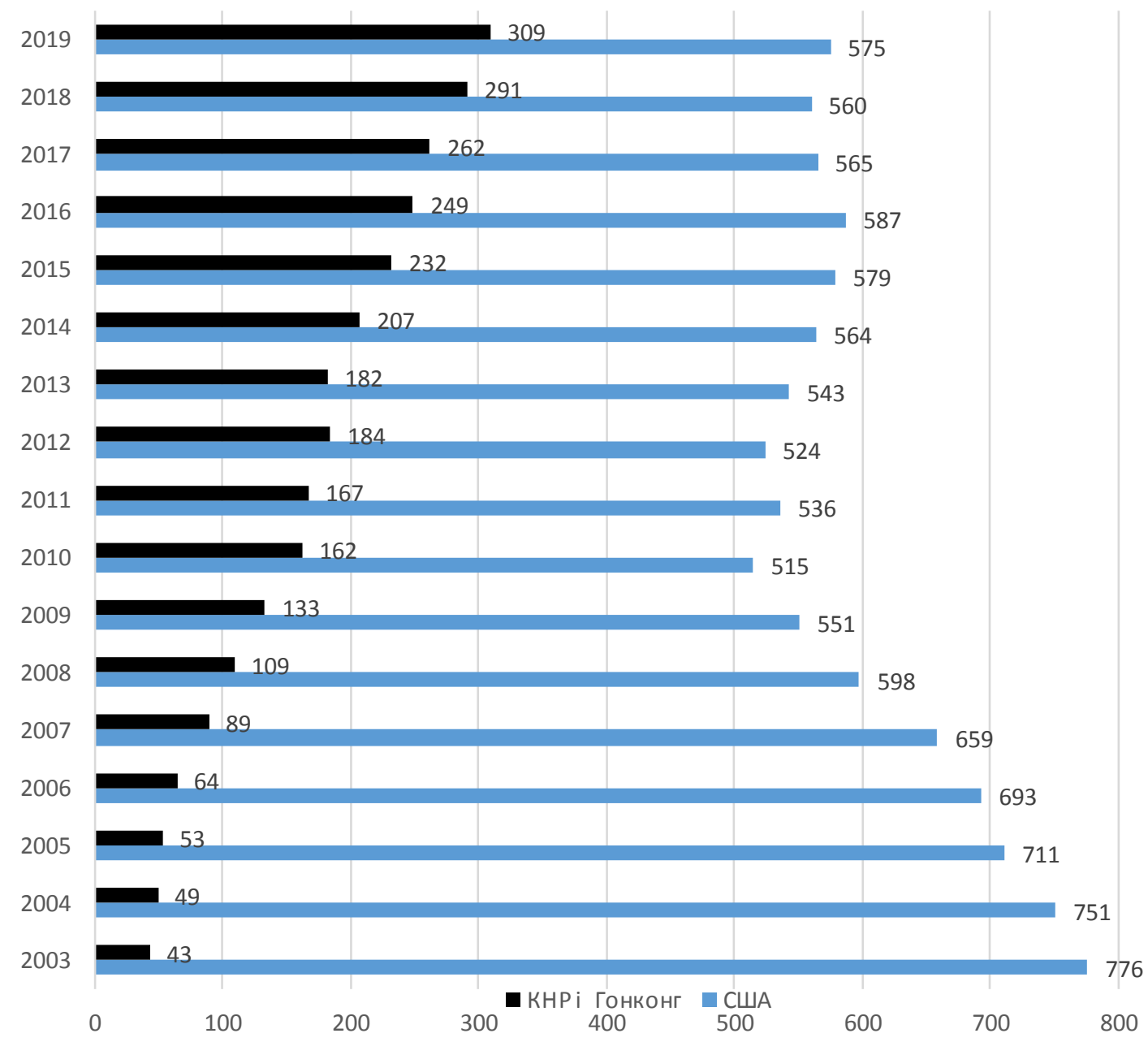

Рис. 2. Динаміка чисельності ТНК у споживчому секторі в США та КНР і Гонконгу [1] 
3 представлених на рис. 2 даних можна зробити висновок про те, що незважаючи на поточне домінування американських компаній у рейтингу лідерів на глобальному ринку, уповільнення темпів зростання ВВП і багатомільярдні тарифи Трампа, фірми з КНР з кожним роком займають все більшу нішу і у найближчому майбутньому складуть жорстку конкуренцію усталеним передовим гравцям цього сектора. Також вперше в історії Китай займає найбільше мість у топ-10. На момент запуску рейтингу Global 2000 у 2003 році Китай та
Гонконг мали у списку лише 43 компанії проти 776 із США. Загалом, уряди розвинених країн зацікавлені у збереженні й розвитку потужних ТНК, які здатні застосовувати гнучкі адаптивні моделі функціонування, незважаючи на обсяги їх діяльності.

Найбільш представленими галузями у списку серед компаній-лідерів $€$ банківська справа та фінанси, до них входять 453 компанії, або трохи більше п'ятої частини заявок.

Таблиця 1. Рейтинг галузей з найбільшою кількістю компаній, що входять в Global 2000 [1]

\begin{tabular}{|l|c|c|c|}
\hline \multicolumn{1}{|c|}{ Галузь } & Кількість & $\begin{array}{c}\text { Загальні активи, } \\
\text { млрд. дол. США }\end{array}$ & $\begin{array}{c}\text { Загальний прибуток, } \\
\text { млрд. дол. США }\end{array}$ \\
\hline Банківська справа & 308 & 89201,1 & 6331,8 \\
\hline Фінанси & 145 & 19864,9 & 3650,3 \\
\hline Будівництво & 123 & 5223,0 & 1616,2 \\
\hline Нафтогазові операції & 110 & 6494,8 & 4001,6 \\
\hline Страхування & 102 & 20293,9 & 2421,9 \\
\hline Матеріали & 102 & 2382,2 & 1428,2 \\
\hline Товари тривалого користування & 90 & 4699,5 & 1958,4 \\
\hline Бізнес-послугита постачання & 88 & 8051,0 & 2200,9 \\
\hline Комунальні послуги & 84 & 4157,1 & 1576,1 \\
\hline Їжа, напої та тютюн & 75 & 2174,9 & 2842,0 \\
\hline
\end{tabular}

Будівельні фірми, такі як China State Construction Engineering Corp., складають наступну найбільш кількісну категорію галузі. 35\% із 123 компаній цієї категорії - з Китаю, який за останні десять років зазнав значного інфраструктурного буму. Далі йдуть нафтогазові компанії, за ними йдуть страхові та матеріальні компанії, такі як американський виробник алюмінію Alcoa.

Як видно з таблиці 1 компанії, що працюють у банківській сфері також мають найбільший прибуток та найбільші активи. Великі активи також мають компанії у галузі страхування (20293,9 млрд. дол. США) та фінансів (19864,9 млрд. дол. США). У рейтингу прибутку за банківською сферою слідують нафтогазові компанії (4001,6 млрд. дол. США), фінансові (3650,3 млрд. дол. США) та компанії, що працюють у сфері їжі, напоїв та тютюну $(2842,0$ млрд. дол. США).

На рис. 3 подано приріст прибутку компаній за галузями економіці. Як свідчать дані, найбільший приріст прибутку у 2019-му році, що становить приблизно 15-20\% спостерігається у компаній, що працюють у нафтогазовій галузі.

$2019 \square 2018$

Нафтогазові операції

Банківська справа

Програмне забезпечення та послиги

Технологічне обладнання

Ліки та біотехнології

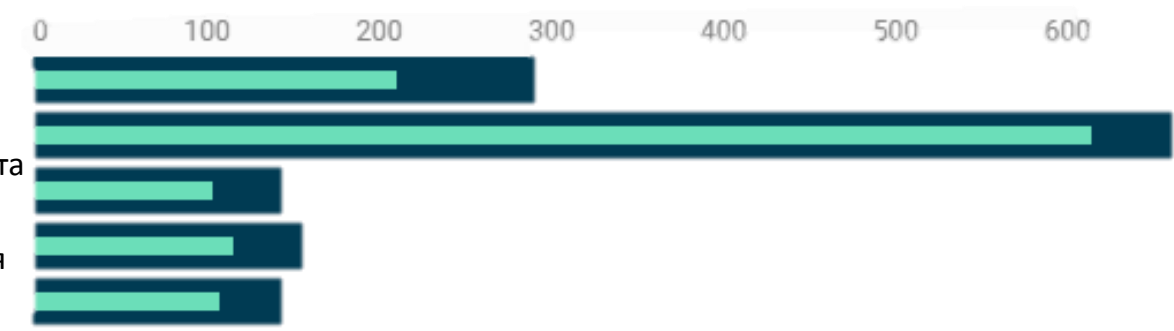

Рис. 3. Приріст прибутку компаній за галузями, у мільярдах доларів [1].

На другому місці знаходяться компанії 3 банківської сфери. Наступні три позиції ділять компанії, що розробляють програмне забезпечення, технологічне обладнання, ліки та 
біотехнології. Їхній приріст знаходиться на приблизно однаковому рівні.

Рейтинг Forbes 2020 серед 2000 найбільших публічних компаній у світі ілюструє масштаби глобальних закриттів і служить попередженням про нові проблеми в найближчі місяці. Ринкова вартість більшості компаній, включених в список Global 2000 цього року, значно впала в порівнянні з минулим роком, і зменшений прибуток за перший квартал дає уявлення про наслідки припинення виробництва.

Останні кілька місяців були особливо жорстокими для авіакомпаній, де попит знизився нижче, ніж після 11 вересня 2001 року. Наприклад, American Airlines впала з № 372 у списку до 967-го після втрати приголомшливих 2,2 млрд. доларів у першому кварталі. Дохід у третьому кварталі зменшився на 73\% у річному обчисленні завдяки скороченню загальної кількості авіамиль на 59\% у річному обчисленні [2].

Також від'ємне занчення прибутку цього року отримала китайська авіакомпанія Hainan Airlines.

Однак не на всі компанії негативно впливає пандемія. Найбільші гравці електронної комерції, включаючи Amazon, Alibaba та Walmart, пережили зростання завдяки зростанню покупок в Інтернеті. Усі троє увійшли до цьогорічного списку. Доходи компанії Amazon збільшились на 27,2 \% у 2020-му році, компанії Alibaba на 36\% та компанії Walmart майже на $2 \%$.

Припинення комерційної діяльності в умовах пандемії Коронавірусу (Covid-19) матиме значний вплив на світову економіку. Оцінки економічного впливу та перегляди доходів 5000 найбільших транснаціональних підприємств, здійснені ЮНКТАД, свідчать про те, що зниження ПІІ, може становити від -30 до -40 відсотків у 2020 та 2021 роках. Зараз 5000 найуспішніших транснаціональних корпорацій прогнозують перегляд своїх прогнозних доходів за 2020 рік у середньому на -30\%, а верхні показники становлять навіть -200\% у найбільш постраждалих галузях (енергетика -208\%, авіакомпанії -116\% та автомобільна промисловість - 47 \%) [3].

Ранні очікування полягали в тому, що економічні наслідки пандемії будуть відчуватися через зупинку виробництва та порушення ланцюга поставок. Завдяки швидкому поширенню пандемії у всьому світі та впровадженню заходів пом'якшення наслідків та карантину у більшості країн світу стає очевидним, що набагато більший шок попиту та порушення поставок неминучі, i консенсус полягає в тому, що більшість, якщо не всі, великі економіки зазнають рецесії.

Фізичне закриття підприємств, виробничих підприємств та будівельних майданчиків спричинило негайні затримки у реалізації інвестиційних проектів. Це впливає на капітальні витрати, зелені інвестиції та розширення. Подібним чином постраждали злиття та поглинання, які в першій половині 2020 року в цілому скоротились на 50-70\% [3].

Пандемія COVID-19 мала нагальний негативний вплив на прямі іноземні інвестиції в 2020 році. Перспективи залишаються жахливими, подальше погіршення прогнозується в 2021 році. Виняткові глобальні обставини в результаті пандемії призвели до затримки реалізації поточних інвестиційних проектів та відкладання нових проектів, а також висихання іноземних надходжень, які, як правило, значну частку реінвестують у країни перебування. Як результат, прогнозується, що глобальні обсяги ПII зменшаться до 40 відсотків у 2020 році зі своєї вартості в 2019 році близько 1,6 трлн. (рис. 4. ) Це призведе до того, що ПІІ становитимуть нижче 1 трлн. дол. США вперше з 2005 року, за прогнозами, ПII ще зменшаться в 2021 році । почнуть відновлюватися лише в 2022 році. Після спалаху COVID-19 ПII миттєво вразив карантин. Однак деякі інвестиційні витрати продовжувались (наприклад, постійні поточні витрати проектів), але інші витрати були заблоковані. Подібним чином багато злиттів та поглинань були або тимчасово призупинені, або скасовані. Регулятори у Сполучених Штатах та Європі повідомили про затримки процесів затвердження деяких запланованих мега-злиттів.

Найбільше падіння пережили розвинені економіки - падіння на 75 \%. Прямі іноземні інвестиції у країнах, що розвиваються в свою чергу зменшились лише на $16 \%$ - менше, ніж очікувалося. Потоки ПІІ були на 28\% нижчими в Африці, на 25\% у Латинській Америці та Карибському басейні та лише на 12\% в Азії, головним чином завдяки стійким інвестиціям у Китай. Найбільш різке падіння ПІІ (на 81\%) спостерігалось у країнах з перехідною економікою через падіння потоків до Російської Федерації, найбільшої з цих економік.

Що стосується усіх форм транскордонних інвестицій, прогнози на 2020 рік і пізніше залишаються невизначеними. 3 точки зору прямих іноземних інвестицій, з другою хвилею пандемії, що підриває зусилля до загального економічного відновлення, майже 50-відсоткове зниження першої половини 2020 року може тривати довше, роблячи прогноз додаткового зниження 2021 року різкішим, ніж спочатку прогнозували 10 відсотків. Перспективи інвестицій залежатимуть від тривалості кризи охорони здоров'я та ефективності політичних заходів щодо пом'якшення економічних наслідків пандемії [5]. 


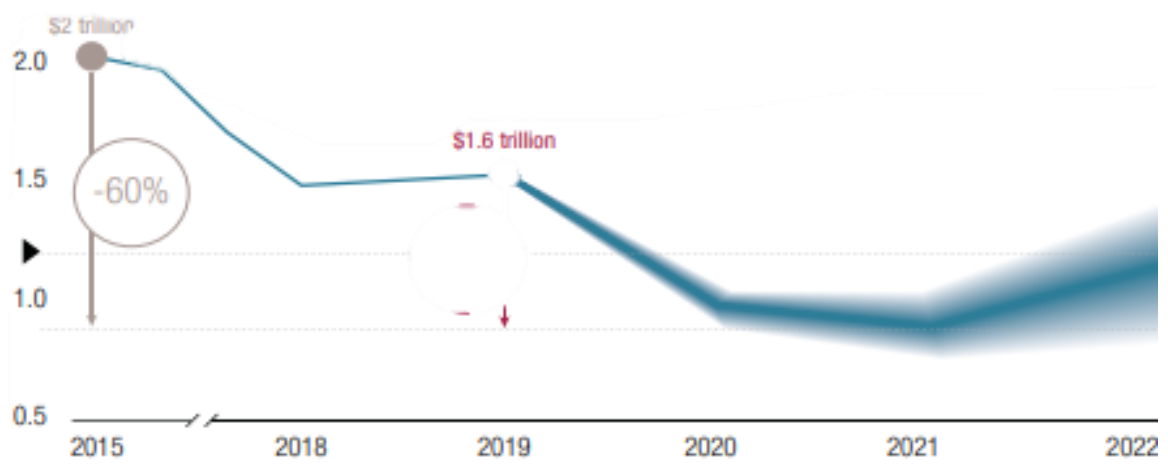

Рис. 4. Глобальний потік прямих іноземних інвестицій [4].

Дані за 2020 рік підтвердили безпосередність впливу. У першій половині року глобальні ПІІ зменшились на $49 \%$ порівняно з 2019 роком (рис. 5).

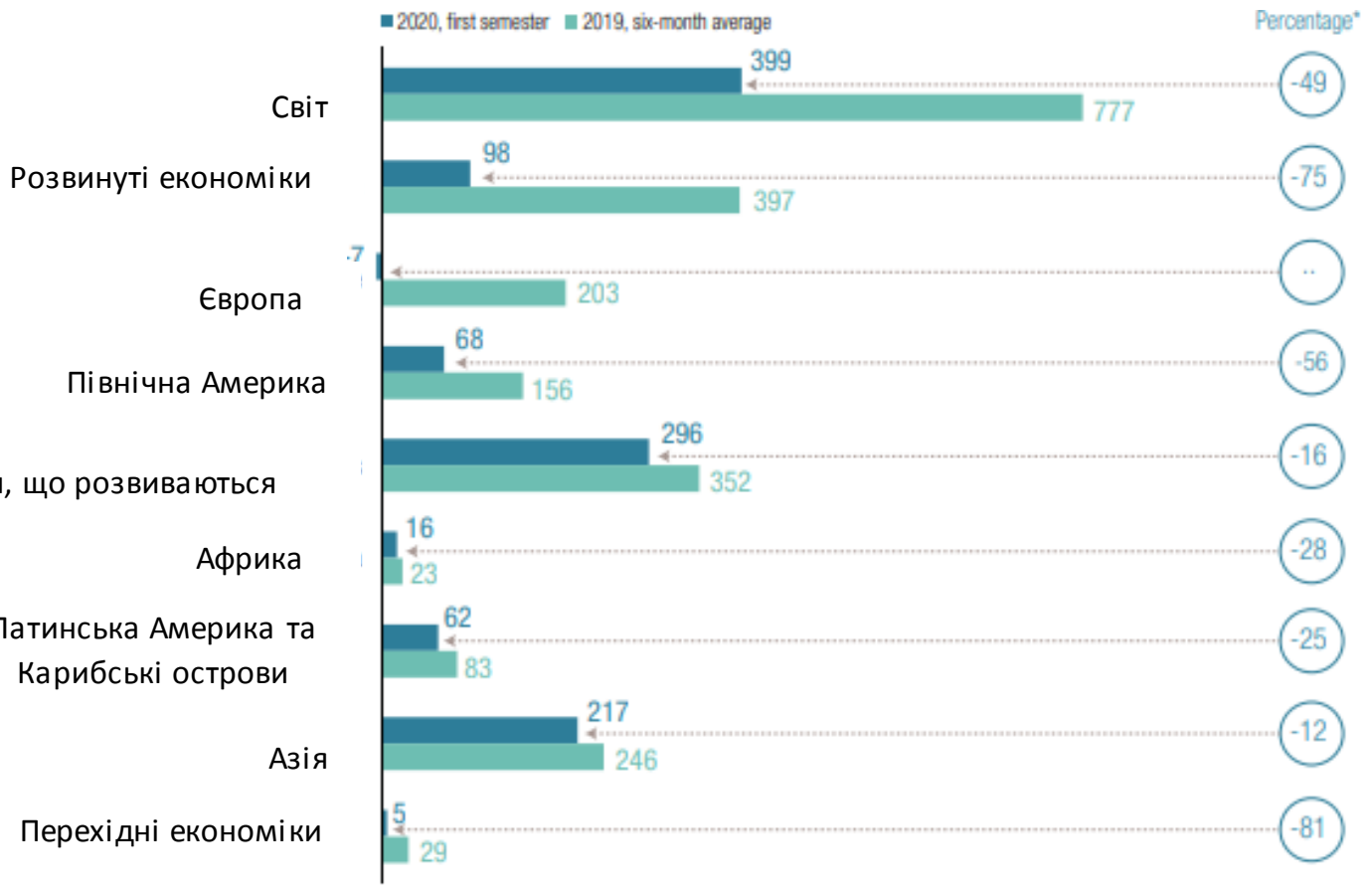

Рис. 5. Глобальний потік прямих іноземних інвестицій за регіонами, млрд. дол. США [4].

Окрім короткострокової адаптації для стримування та усунення найбільш негативних впливів на економіку, поточна криза - це можливість для ТНК та їх глобальних ланцюгів створення вартості, задуматися про міжнародну бізнес-політику та бізнес-моделі.

\section{Висновки та перспективи подальших досліджень}

На підставі аналізу приходимо до висновків, що географічна структура найпотужніших світових ТНК відображує лідерство США серед більшості країн, проте $з$ кожним роком їх роль зменшується та зростає вплив Китаю. Актуалізуються основні галузі, де відбувається основний розвиток ТНК та найбільший приріст прибутку, а саме банківська справа, фінанси, будівництво та нафтогазові операції. Проведене дослідження показало негативний вплив пандемії коронавірусу на діяльність ТНК, що виявляється в зменшенні прямих іноземних інвестицій і спостерігатиметься аж до початку 2022 року в зв'язку з викликаною рецесією. Драматичне падіння спостерігатиметься як у розвинутих країнах (75\%) так і в країнах 3 перехідною економікою (81\%). Реалії свідчать, що найбільші збитки зазнали ТНК у галузі туризму, наприклад авіакомпанії. Проте особливий зріст спостерігається серед компанійу галузі електронної комерції. 


\section{СПИСОК ВИКОРИСТАНИХ ДЖЕРЕЛ}

1. Ponciano J., Hansen S. The World's Largest Public Companies 2019: Global 2000 By The Numbers. URL: https://www.forbes.com/sites/jonat hanponciano/2019/05/15/worlds largest-companies-2019-global2000/?sh=636d74d74ada.
2. American Airline Financial Results Report Third-Quarter 2020. URL: https://news. aa.com/news/newsdetails/2020/American-AirlinesReports-Third-Quarter-2020-

Financial-Results-CORP-FI-

10/default.

aspx\#: :text=American\%20Airlines\% 20Reports\%20Third\%2DQuarter\%20 2020\%20Financial\%20Results,Thurs day\%2C\%200ctober\%2022\&te $\mathrm{xt}=($ NASDAQ\%3A\%20AAL)\%20today \%20reported, available\%20s ea $\% 20$ miles\%20(ASMs).
3. OECD, Transnational corporation investment and development 2020, Number $1 . \quad$ URL: https://unctad.org/system/files/offi cial-

document/diaeia2020d1_en.pdf.

4. OECD, Impact of Covid-19 Pandemic on Trade and Development. URL: https://unctad.org/system/files/offi cial-document/osg2020d1_en.pdf.

5. OECD, Transnational corporation investment and development 2020, Number $2 . \quad$ URL: https://unctad.org/system/files/offi cial-

document/diaeia2020d2_en.pdf.

\section{ReferenCES}

1. Ponciano J., Hansen S. (2019). The World's Largest Public Companies 2019: Global 2000 By The Numbers. Retrieved from: https://www.forbes.com/sites/jonat hanponciano/2019/05/15/worldslargest-companies-2019-global2000/?sh=636d74d74ada.
2. American Airline Financial Results Report Third-Quarter 2020. Retrieved from: https://news.aa.com/news/newsdetails/2020/American-AirlinesReports-Third-Quarter-2020-

Financial-Results-CORP-FI-

10/default.aspx\#: :text=America $\%$ 20Airlines\%20Reports\%20Third\%2D Quarter\%202020\%20Financial\%20R esults,-

Thursday\%2C\%200ctober\%2022\&te $x t=($ NASDAQ\%3A\%20AAL)\%20today $\% 20$ reported,available $\% 20$ seat $\% 20$ miles\%20(ASMs).
3. OECD (2020). Transnational corporation investment and development 2020. Retrieved from: https://unctad.org/system/files/offi cial-

document/diaeia2020d1_en.pdf.

4. OECD (2020). Impact of Covid-19 Pandemic on Trade and Development. Retrieved from: https://unctad.org/system/files/offi cial-document/osg2020d1_en.pdf.

5. OECD (2020). Transnational corporation investment and development. Retrieved from: https://unctad.org/system/files/offi cial-

document/diaeia2020d2_en.pdf. 